\title{
Analysis of the Russian-Chinese economic correlation in the field of foreign trade relations in the pandemic
}

\author{
Elena Sinianskaia ${ }^{1}$, Olga Savostina ${ }^{1, *}$, and $X u$ Rui $^{1}$ \\ ${ }^{1}$ Ural Federal University, 620075, Mira St., 19, Ekaterinburg, Russia
}

\begin{abstract}
The article deals with the issues of improving analytical support for risk assessment using the SWOT analysis of internal and external environment factors through the example of Russian-Chinese economic cooperation in the field of trade. The analysis of the structural components of the most significant indicators of Russian-Chinese trade flows for the period of 2017-2018, preceding the COVID-19 pandemic, and the dynamics of export-import operations from January 2019 to June 2020 during the introduction of restrictive measures were performed. Besides, the additional impact of the simultaneously developing currency crisis in Russia and possible measures to overcome it at the bilateral level were considered. Based on the indicators of a very rapid return of Russian-Chinese foreign trade relations to close to pre-crisis ones within a short time, it can be assumed that an integrated approach to assessing, planning, and monitoring internal and external risks in the short and long term gives a positive result. Therefore, the traditional analysis of internal factors that are the most predictable and subject to constant control by organisational leadership must be coordinated with a thorough analysis of uncertainty factors, which allows adapting to the rapidly changing business environment as quickly as possible. As a result, the effectiveness of strategic planning and strategic analysis is significantly increased.
\end{abstract}

\section{Introduction}

The analysis of economic risks in organisations is carried out in scientific research using various methods, the most optimal of which from the point of view of a comprehensive approach is the SWOT analysis, which includes the study of the impact of external and internal factors. Due to the impact of uncertainty circumstances on the external environment, the analysis of external factors is the weakest link compared to the internal factors controlled by organisational leadership.

In the course of this research, the authors considered the problems of identifying external risk factors that affect the effectiveness of SWOT analysis of commercial organisations' activities.

The following works are devoted to risk research: works by J. Bessil, R. Gallagher, K. Dowd, M. Crui, D. Galai, R. Mark, R. Mattessich, and others [1-5].

${ }^{*}$ Corresponding author: o.v.savostina@urfu.ru 
Let us consider the complex of risks associated with the uncertainty factor in the pandemic through the example of Russian-Chinese economic cooperation, first of all, in the field of foreign trade.

Russian-Chinese trade and economic ties have a long history, due to the presence of a significant amount of border territories and transport infrastructure. The continuous strengthening of partnership relations both in the field of bilateral trade and in the field of production and financial activities helps to improve the efficiency of both countries' economies. However, under the influence of external political and economic factors, there are certain deviations in the overall picture of positive dynamics. Thus, in 2008, the volume of Chinese-Russian trade increased to 56 billion US dollars, but under the influence of the international financial crisis in 2009, it decreased to 40 billion US dollars. After that, it continued to grow and stabilised in the range of 80 to 90 billion US dollars. In 2010, China became Russia's largest trading partner. However, due to the crisis in Ukraine and the subsequent economic sanctions, as well as the collapse of world oil prices, which led to a sharp depreciation of the Russian ruble, the scale of Chinese-Russian trade again fell to 60 billion US dollars. After a two-year adaptation period, the volume of bilateral trade eventually exceeded 100 billion US dollars by 2018 [6].

In autumn 2019, the rapid development of the COVID-19 pandemic began in China, causing damage to both the country's domestic economy and foreign trade relations with Russia. The closure of Russian borders since March 2020 has significantly worsened the situation. The most critical months of 2019-2020 were selected for this research; the analysis of changes over these periods revealed the main risk factors for foreign trade relations between Russia and China.

\section{Materials and Methods}

In the process of studying business risk factors in strategic planning using the SWOT analysis method, it is customary to highlight the strengths and weaknesses of a commercial organisation's activities, including external and internal ones. At the same time, among the external uncertainty factors, the influence of the political situation, stock quotes, tax and customs policies of the cooperating states, and industry specifics are most often indicated. Methods of structural analysis of official statistics, as well as comparative analysis in dynamics over the most significant time ranges, are very effective for identifying their combined impact. This paper uses the volumes of the analysed set of statistical indicators from both the Russian and Chinese sides.

Chinese imports of goods from Russia mainly include mineral products, wood and industrial goods, chemical products, finished products of heavy industry, machinery and electrical products, while Chinese exports to Russia mainly include light industry products, electromechanical products, textile fabrics, and their raw materials. This is because China and Russia have a very significant complementarity of industrial structures. China is a country with a large labour force and a clear advantage in labour-intensive industries, while Russia is a supplier of natural resources, which determines the structure of commodity flows.

The structural components of the most significant indicators (more than $2 \%$ of the total volume) of Russian-Chinese trade flows [7] are presented in Tables 1, 2. 
Table 1. Russia's exports to China in 2018 by the most significant product groups.

\begin{tabular}{|c|c|c|c|c|}
\hline Name of the product group & $\begin{array}{c}\text { Exports in } \\
\mathbf{2 0 1 8} \\
\text { (thousand } \\
\text { US dollars) }\end{array}$ & $\begin{array}{c}\text { Share in } \\
\text { total } \\
\text { exports } \\
\text { (\%) }\end{array}$ & $\begin{array}{c}\text { Exports in } \\
\mathbf{2 0 1 7} \\
\text { (thousand } \\
\text { US dollars) }\end{array}$ & $\begin{array}{c}\text { Changes in } \\
\mathbf{2 0 1 8} \\
\text { compared to } \\
\mathbf{2 0 1 7}(\mathbf{\%})\end{array}$ \\
\hline $\begin{array}{c}\text { Fish and crustaceans, molluscs } \\
\text { and other aquatic invertebrates }\end{array}$ & $1,492,941$ & 2.66 & $1,089,124$ & 37.08 \\
\hline Ores, slag and ash & $1,394,461$ & 2.49 & $1,041,582$ & 33.88 \\
\hline $\begin{array}{c}\text { Mineral fuel, oil and products of } \\
\text { their distillation; bituminous } \\
\text { substances; mineral waxes }\end{array}$ & $41,226,438$ & 73.53 & $25,263,458$ & 63.19 \\
\hline $\begin{array}{c}\text { Wood and wood products; } \\
\text { charcoal }\end{array}$ & $3,553,207$ & 6.34 & $3,265,292$ & 8.82 \\
\hline Copper and copper products & $1,097,055$ & 1.96 & 482,429 & 127.40 \\
\hline $\begin{array}{c}\text { Nuclear reactors, boilers, } \\
\text { equipment and mechanical } \\
\text { devices; their parts }\end{array}$ & $1,509,263$ & 2.69 & $1,564,463$ & -3.53 \\
\hline
\end{tabular}

Table 2. Russia's imports to China in 2018 by the most significant product groups.

\begin{tabular}{|c|c|c|c|c|}
\hline Name of the product group & $\begin{array}{c}\text { Imports } \\
\text { in } 2018 \\
\text { (thousand } \\
\text { US } \\
\text { dollars) } \\
\end{array}$ & $\begin{array}{c}\text { Share in } \\
\text { total } \\
\text { imports } \\
(\%)\end{array}$ & $\begin{array}{c}\text { Imports in } \\
2017 \\
\text { (thousand } \\
\text { US dollars) }\end{array}$ & $\begin{array}{c}\text { Changes in } \\
2018 \\
\text { compared to } \\
2017(\%)\end{array}$ \\
\hline Organic chemical compounds & $1,371,837$ & 2.63 & $1,151,120$ & 19.17 \\
\hline $\begin{array}{l}\text { Plastics and products made from } \\
\text { them }\end{array}$ & $1,766,018$ & 3.38 & $1,477,017$ & 19.57 \\
\hline $\begin{array}{l}\text { Caoutchouc, rubber and products } \\
\text { made from them }\end{array}$ & 569,193 & 1.09 & 485,056 & 17.35 \\
\hline $\begin{array}{l}\text { Articles of clothing and accessories, } \\
\text { knitted or crocheted }\end{array}$ & $1,088,024$ & 2.08 & $1,102,440$ & -1.31 \\
\hline $\begin{array}{l}\text { Articles of clothing and accessories } \\
\text { other than knitted or crocheted } \\
\text { items }\end{array}$ & $1,503,046$ & 2.88 & $1,428,239$ & 5.24 \\
\hline $\begin{array}{l}\text { Footwear, gaiters and similar } \\
\text { products; their details }\end{array}$ & $1,810,356$ & 3.47 & $1,643,495$ & 10.15 \\
\hline Ferrous metals & 737,797 & 1.41 & 689,958 & 6.93 \\
\hline Ferrous metal products & $1,474,995$ & 2.82 & $1,209,607$ & 21.94 \\
\hline $\begin{array}{l}\text { Tools, implements, cutlery, spoons } \\
\text { and forks of base metals; parts } \\
\text { thereof of base metals }\end{array}$ & 605,851 & 1.16 & 507,905 & 19.28 \\
\hline $\begin{array}{l}\text { Nuclear reactors, boilers, equipment } \\
\text { and mechanical devices; their parts }\end{array}$ & $\begin{array}{c}12,075,72 \\
7 \\
\end{array}$ & 2.13 & $13,641,959$ & -11.48 \\
\hline $\begin{array}{l}\text { Electrical machinery and } \\
\text { equipment, their parts; sound } \\
\text { recording and reproducing } \\
\text { equipment, equipment for recording } \\
\text { and reproducing television images } \\
\text { and sound, their parts and } \\
\text { accessories }\end{array}$ & $\begin{array}{c}14,382,54 \\
8\end{array}$ & 27.54 & $11,804,147$ & 21.84 \\
\hline
\end{tabular}




\begin{tabular}{|c|c|c|c|c|}
\hline $\begin{array}{c}\text { Means of land transport, except for } \\
\text { railway or tram rolling stock, their } \\
\text { parts and accessories }\end{array}$ & $1,918,669$ & 3.67 & $1,675,554$ & 14.51 \\
\hline $\begin{array}{c}\text { Optical, photographic, } \\
\text { cinematographic, measuring, } \\
\text { control, precision, medical or } \\
\text { surgical instruments and apparatus; } \\
\text { their parts and accessories }\end{array}$ & $1,101,630$ & 2.11 & 950,801 & 15.86 \\
\hline $\begin{array}{c}\text { Furniture; bedding, mattresses, } \\
\text { mattress supports, cushions and } \\
\text { similar stuffed furniture } \\
\text { accessories; lamps and lighting } \\
\text { fittings, not elsewhere specified or } \\
\text { included; illuminated signs, } \\
\text { illuminated plaques with a name or } \\
\text { title or address and the like; } \\
\text { prefabricated building structures }\end{array}$ & 963,390 & 1.84 & $1,020,276$ & -5.58 \\
\hline $\begin{array}{c}\text { Toys, games and sports equipment; } \\
\text { their parts and accessories }\end{array}$ & $1,504,162$ & 2.88 & $1,373,663$ & 9.50 \\
\hline
\end{tabular}

According to the overall review of statistics on Russia's foreign trade in 2018, Russia's trade turnover with China amounted to $108,283,490$ thousand US dollars, an increase of $24.51 \%$ compared to 2017, and Russia's exports to China, respectively, amounted to $56,065,497$ thousand US dollars, an increase of 44.05\%. Russia's imports from China in 2018 amounted to 52,217,993 thousand US dollars, an increase of $8.69 \%$ compared to 2017 .

The share of China in Russia's exports in 2018 was $12 \%$ against $11 \%$ in 2017; the share of China in Russia's imports in 2018 was $22 \%$ against $21 \%$ in 2017 . The share of China in Russia's foreign trade turnover was $15.7 \%$ in 2018 and 14.9\% in 2017; according to all these indicators, China took 1st place both years [8].

Thus, in the years leading up to the pandemic, Russian-Chinese trade relations developed on mutually beneficial terms and tended to further correlate with positive economic effects.

Next, let's look at the changes that occurred under the influence of unpredictable conditions. As already mentioned, in addition to the direct impact of negative factors, there was also a time gap of about six months in the introduction of restrictive measures and the closure of borders. In China, this happened in autumn 2019, and in Russia - in spring 2020.

Figs. 1-4 show data on changes from January 2019 to June 2020 according to Chinese customs statistics $[9,10]$.

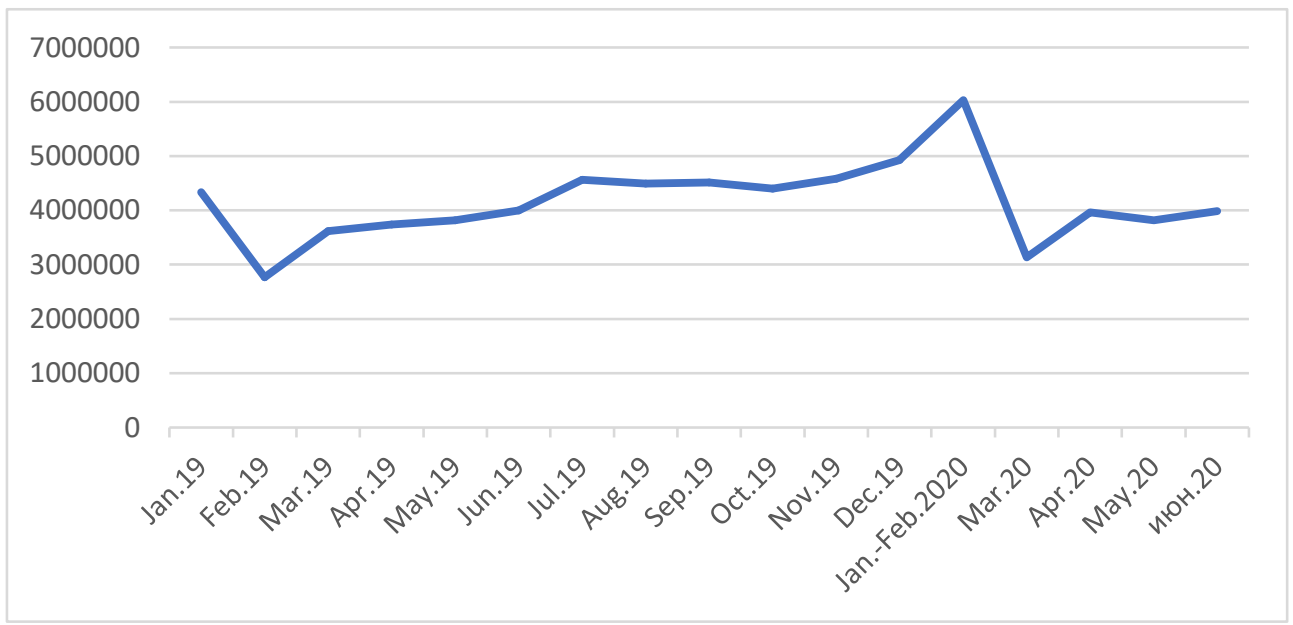


Fig. 1. Exports from China to Russia in value terms (thousand US dollars).

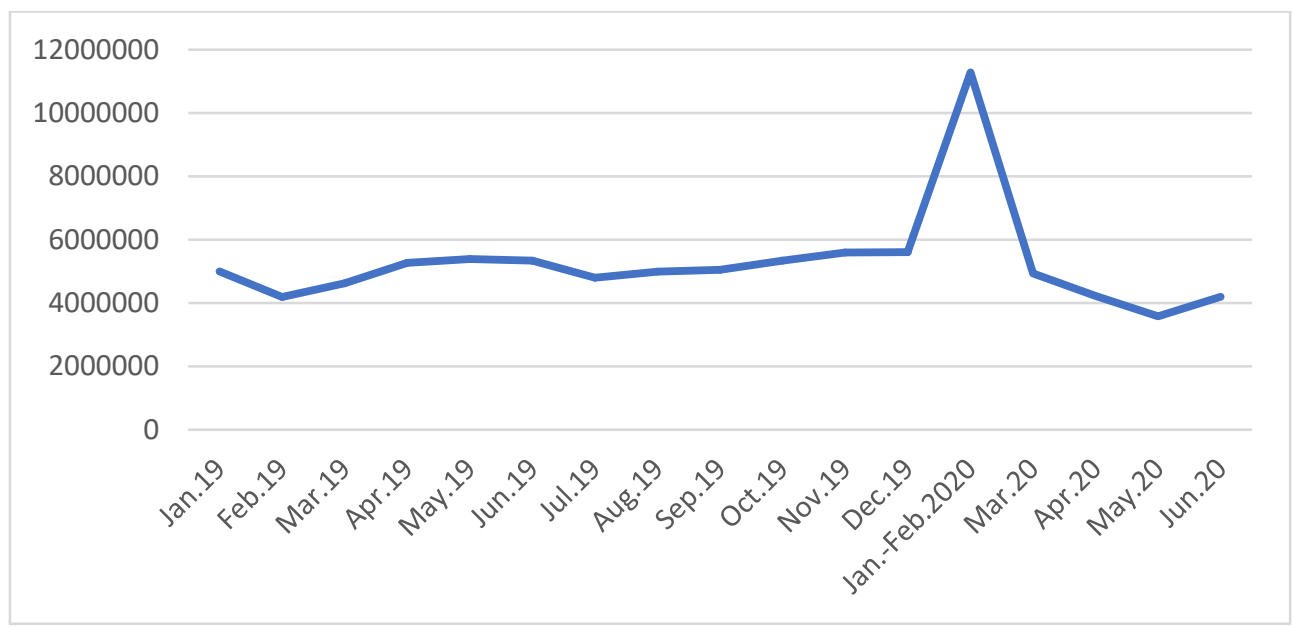

Fig. 2. Imports from China to Russia in value terms (thousand US dollars).

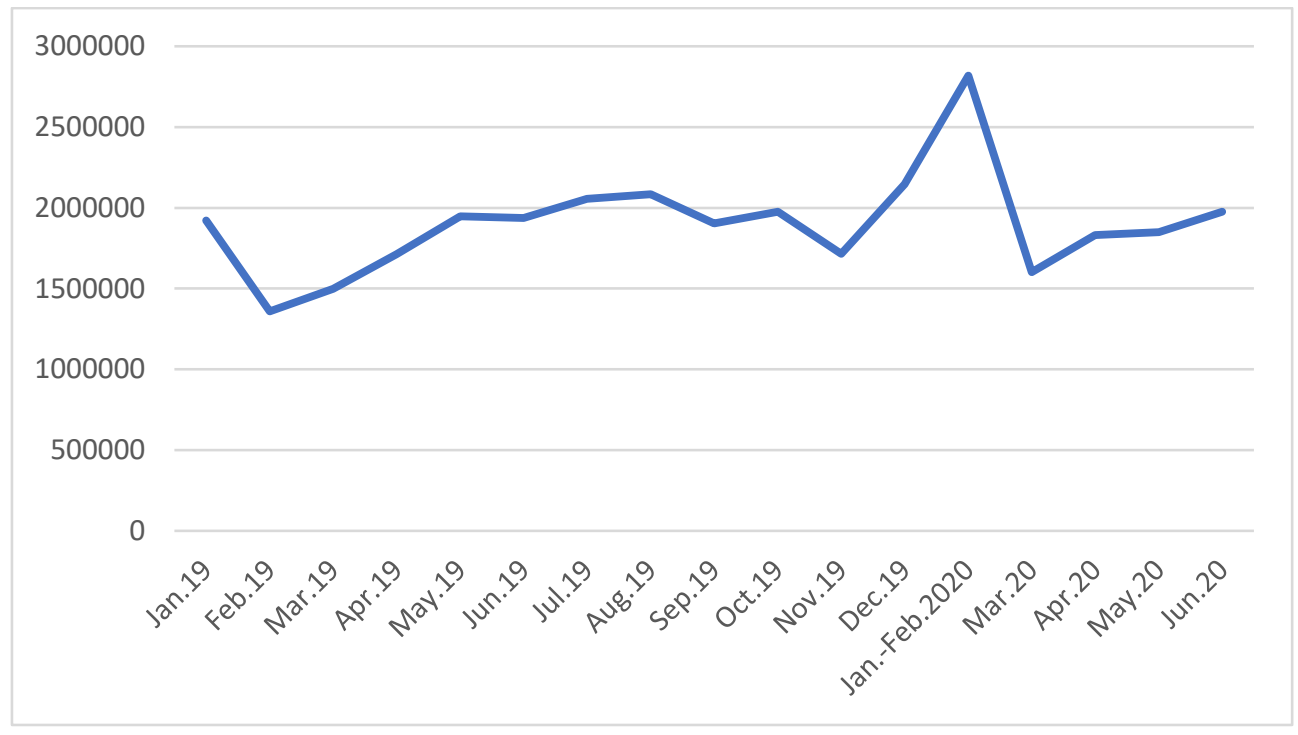

Fig. 3. The volume of exports from China to Russia (number of transactions). 


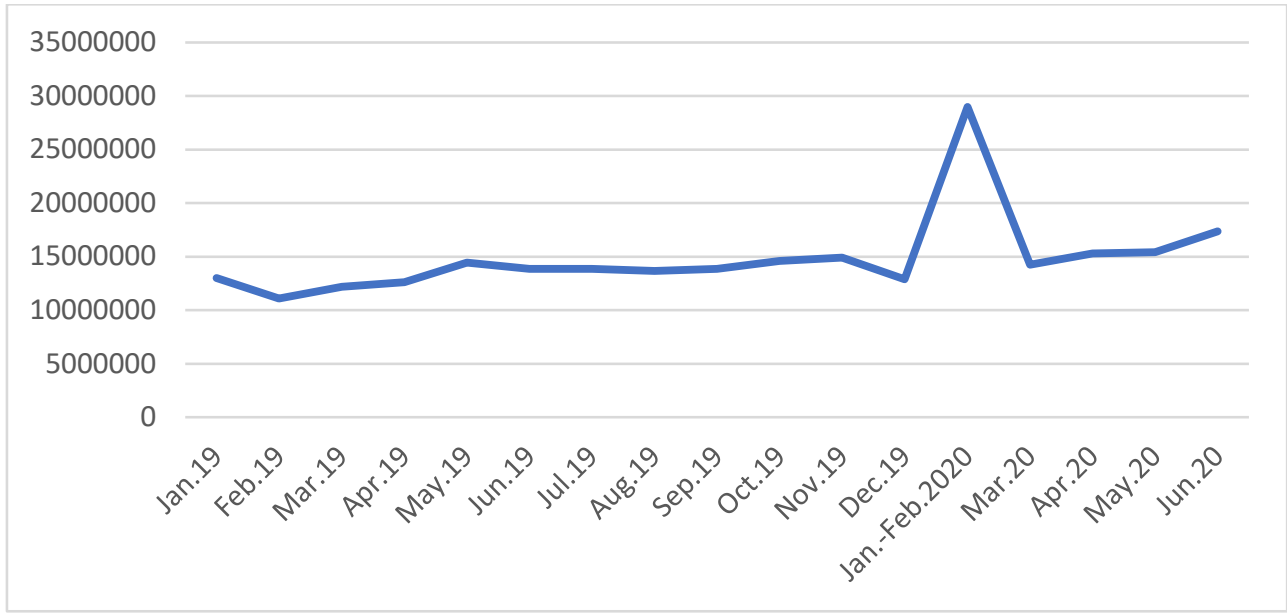

Fig. 4. The volume of imports from China to Russia (number of transactions).

As can be seen from the presented graphs, both exports and imports were fairly stable throughout 2019 until November, when the beginning of the pandemic in China was announced. Then there was a significant surge in business activity from December to March. This was most likely due not so much to warranty conditions in China, but to the traditional growth of commodity flows due to the end of the calendar and financial year, and New Year's holidays in both countries. Further, there was a significant drop due to the introduction of restrictive measures in Russia in late March - April 2020. Further, there was a slight increase in indicators, but by June this increase stabilised.

In addition to the main cause of the global economic crisis caused by the COVID-19 pandemic, there are a number of other external risk factors that destabilise the development of Russian-Chinese trade relations. Let us note some of them.

Almost simultaneously with the beginning of the spread of the pandemic from China around the world in November - December 2019, the fall in oil prices began. There were also negative consequences due to the introduction of economic sanctions against both Russian and Chinese companies. These two combined factors caused a rapid fall in the ruble exchange rate, which continued throughout spring and summer 2020.

The currency crisis associated with the devaluation of the ruble against the US dollar and the euro damaged not only foreign trade transactions but also Chinese enterprises and organisations doing business in the Russian Federation.

As a protective measure and risk reduction, including in the pandemic, one can consider such financial instruments that involve the use of a direct exchange rate between the ruble and the yuan.

For example, on December 26, 2014, the China Foreign Exchange Trading Center of the People's Bank of China launched a forward contract for the exchange rate of the yuan against the ruble, which has the effect of blocking the future exchange rate of the ruble. Company A, as an exporter, exports a batch of goods to a Russian company with the condition that it is denominated in rubles, and the price is 7 million rubles and will be paid in three months. Currently, the exchange rate of the yuan against the ruble is 1 yuan $=7$ rubles. Three months later, due to the impact of the ruble crisis, the ruble exchange rate became 1 yuan $=9$ rubles. Then, three months later, the actual payment received by Company A was 780,000 yuan, and the ruble depreciation reduced it by 220,000 yuan. Income in yuan: if Company A signed a three-month forward currency contract for the ruble against the ruble three months ago and agreed that the exchange rate of the yuan against the ruble in three months would be 1 yuan 
$=8$ rubles, then Company A will receive a payment of 875,000 yuan months later, which is 95,000 fewer losses than a short currency forward.

As another example, let us note the introduction of futures contracts by the Russian side, which can allow companies to effectively hedge losses in the spot market. Russian Company A exports a batch of goods to Russian Company B denominated in rubles. The price is 7 million rubles, which will be paid in three months. Currently, the exchange rate of the yuan against the ruble is 1 yuan $=7$ rubles. It is said that the current accounts receivable of 7 million rubles if received now, could be 1 million yuan. Assuming that the exchange rate of the yuan against the ruble is 1 yuan $=10$ rubles in three months, then the actual currency payment in yuan that can be received in three months will be 700,000 yuan. If Company A adopts the strategy of a futures contract with short sales of rubles, if the futures contract is 1 yuan $=7$ rubles, and in three months the futures contract is 1 yuan $=9.5$ rubles, then Company A will make a profit of 263,300 yuan. As a result, the total revenue of the futures market and the spot market is 36,800 yuan. It is seen that the use of futures contracts effectively hedges losses in the spot market.

\section{Results and Discussion}

Using the methods of structural and comparative analysis of statistical data of two countries as foreign economic elements of the SWOT analysis method allowed identifying the following problems and possible directions for their solution.

During the period from 2015 to 2019, the Russian-Chinese relations, preceding the COVID-19 pandemic, developed on mutually beneficial terms and, despite slight fluctuations, had a general tendency to correlate both export-import operations and joint production and economic activities in the territory of both countries, especially in the border territories.

From November 2019 to February 2020, despite the beginning of the pandemic spread, there was a sharp increase in trade turnover for both exports and imports. It was due to both traditional factors of New Year's holidays and the need to complete transactions by counterparties in the context of the likelihood of the upcoming closure of borders, first from the Chinese and then from the Russian side. Further, after the actual introduction of restrictive measures by Russia in March - April 2020, there was a decrease in business activity. Gradually, within the next two months, the situation was levelling off and, although it has not yet reached the pre-crisis levels, there was a tendency to stabilise both in quantitative and financial indicators.

In parallel with the impact of business restrictions caused by the pandemic, the currency crisis in Russia, caused by falling oil prices and international sanctions, is also worsening. The crisis also has a negative impact on Chinese counterparties. As a priority for long-term bilateral transactions, it is assumed to carry out settlements directly at the exchange rates of the yuan against the ruble in order to reduce the negative impact of the currency crisis.

\section{Conclusions}

So, after analysing the data provided in the article on changes in foreign trade relations between Russia and China under normal conditions and the influence of such uncertainty factors as the COVID-19 pandemic and the currency crisis, the following conclusions can be drawn regarding the improvement of methods for assessing financial and economic risks and conducting the SWOT analysis.

In the strategic planning of financial and economic activities of organisations, the greatest attention is traditionally paid to the analysis of internal factors or the immediate environment, 
since they are the most predictable and subject to constant control by a leadership. Analysis of the impact of external factors and assessment of risks, associated with uncertainty conditions for many entrepreneurs, cause significant difficulties. However, as the conducted research has shown, it was external factors that had a significant impact on the economy of both countries, and on bilateral relations in the field of production and trade.

Moreover, this impact can be divided into two directions. First, it concerns strategic analysis within the organisation itself, which helps to adapt to the rapidly changing business environment as quickly as possible. This aspect is directly related to the opportunities for improving internal business processes and human resources. On the other hand, such global economic crises cannot take place without the state support of both the organisations themselves and the preservation of the foreign trade balance between two countries.

The scientific novelty of the research is the identification of risk factors that contributes to improving the effectiveness of the SWOT analysis method in strategic planning. Concerning the analysed problem, it is advisable to distinguish two groups of factors:

- $\quad$ external factors of a predictable nature, due to the permanent development of the world economic system and foreign policy relations of leading countries (in this case, these include the economic sanctions of the USA and European countries in relation to both Russia and PRC, the instability of oil prices, the instability of national currencies in relation to the dollar and euro);

- $\quad$ external factors of an unpredictable nature, requiring the ability to quickly adapt to rapidly changing socio-economic and political conditions (COVID-19 pandemic).

A comprehensive approach to assessing internal and external risks in the short and long term has a positive effect, as shown by the results of a very rapid return of Russian-Chinese foreign trade relations to indicators close to pre-crisis levels for a short time.

\section{References}

1. J. Bessil, Risk Management in Banking (New York: John Wiley Inc, 2009)

2. R.B. Gallagher, Risk Management: A New Phase of Cost Control. Harvard Business Review, 34(5) (1956)

3. K. Dowd, The Analytics of Risk Model Validation (In Quantitative Finance, 2008)

4. M. Crui, D. Galai, R. Mark, Fundamentals of Risk Management (Moscow: Yurayt, 2017)

5. R. Mattessich, Accounting and Analytical Methods (D Irwin Inc, 1964)

6. N. Wang, Russian-Chinese Research, 1(1) (2017)

7. B.E. Gavrilova, A Look at Russian-Chinese Financial Cooperation from the Point of View of Jin Dongan. North-East Asia, 5, (2016)

8. Foreign Trade of Russia (Statistical Data). Retrieved November 17, 2020, from https://russian-trade.com/reports-and-reviews/2019-02/torgovlya-mezhdu-rossiey-ikitaem-v-2018-g/

9. Trade Statistics. Customs Service, Retrieved November 17, 2020, from https://unipass.customs.go.kr/ets/

10. Interactive Tables. Custom Statistics, Retrieved November 17, 2020, from http://43.248.49.97/indexEn 